Journal of Southeast Asian

Journal of Southeast Asian American

Education and Advancement

American Education and

Advancement

Volume 15

Issue 2 Voices from the Field: Centering

Southeast Asian Americans through Policy,

Article 10

Practice, and Activism

2020

\title{
Pride Started with a Riot!
}

Cameron PajYeeb Yang

Coalition of Asian American Leaders Minnesota, cameron@caalmn.org

Follow this and additional works at: https://docs.lib.purdue.edu/jsaaea

Part of the Bilingual, Multilingual, and Multicultural Education Commons

\section{Recommended Citation}

Yang, Cameron PajYeeb (2020) "Pride Started with a Riot!," Journal of Southeast Asian American Education and Advancement: Vol. 15 : Iss. 2, Article 10.

DOI: $10.7771 / 2153-8999.1212$

Available at: https://docs.lib.purdue.edu/jsaaea/vol15/iss2/10

This document has been made available through Purdue e-Pubs, a service of the Purdue University Libraries. Please contact epubs@purdue.edu for additional information.

This is an Open Access journal. This means that it uses a funding model that does not charge readers or their institutions for access. Readers may freely read, download, copy, distribute, print, search, or link to the full texts of articles. This journal is covered under the CC BY-NC-ND license. 


\section{JSAAEA Journal of Southeast Asian American
Education and Advancement}

Vol. 15 Iss. 2 Special Issue (2020) www.JSAAEA.org

\section{Pride Started with a Riot!}

\section{Cameron PajYeeb Yang \\ Coalition of Asian American Leaders Minnesota (CAALMN)}

Trigger warning: Description of death by police brutality

June is Pride Month. I celebrate it each year to say loudly that LGBTQ+ folks should be able to be out and open about their sexuality and gender without fear of arrest, and to honor the Stonewall Riots. This means that my rights as a Queer and Transgender individual began with a riot started by Black and Brown Transgender women (\#SayTheirNames \#MarshaPJohnson and \#SylviaRivera). My Black and Brown siblings have often bore the brunt of police brutality, and it's our time to be in solidarity with them.

As I watched George Floyd's killing, and joined the actions that have followed since, I also began having conversations with my family and friends. I was often met with anti-Blackness and transphobic rhetoric, and found myself emotionally drained. Some frequent questions that come up are "What about us? The Asian community?" or "They don't care about us so why should I care about them?" moments like this remind me that my entire livelihood and liberation is tied to the justice and liberation of the Black community. As a Queer, Transgender, Hmong individual, I am often challenged with this mentality of exclusion and separation of all my identities. Intersectionality is important. I can only fully show up as myself if all of my identities are recognized, validated, and liberated.

Below shows a small yet important table of the rate per 100,000 Black Transgender folk are killed in 2016/17. These transgender women are a part of my community, and I refuse to erase this part of my identity.

\begin{tabular}{|c|c|c|}
\hline \multirow[t]{2}{*}{ Homicide } & rate per 10 & 000 people \\
\hline & EVERYONE & TRANS FOLK \\
\hline TOTAL & 6 & 13 \\
\hline BLACK & 23 & 1170 \\
\hline HISPANIC & 5 & 55 \\
\hline
\end{tabular}

Sources: Center for Disease Control \& Prevention, 2016. American Journal of Public Health, 2017.

\footnotetext{
@)

SDRERIIEHISRESEREEDReaders are free to copy, display, and distribute this article, as long as the work is attributed to the author(s) and the Journal of Southeast Asian American Education \& Advancement, it is distributed for non-commercial purposes only, and no alteration or transformation is made in the work. More details of this Creative Commons license are available at http://creativecommons.org/licenses/by-nc-nd/3.0/. All other uses must be approved by the author(s) or JSAAEA. Journal of Southeast Asian American Education \& Advancement, Vol. 15. Iss. 2. (2020) ISSN: 2153-8999
} 
Stonewall's legacy is a reminder that ending the violence and harm of policing on Black and trans communities should matter to all of us. Yet there have been many moments where I was the only Asian individual in police brutality or violence against people of color organizing spaces. In this moment, as Asian communities across the country are confronting their role in anti-Blackness, I hope we'll honor the fact that the first Pride was a riot and be spurred into showing up and taking action. Celebrate Pride with me and CAAL by working for a world where all Black peopleincluding Black trans women — can be free and thriving.

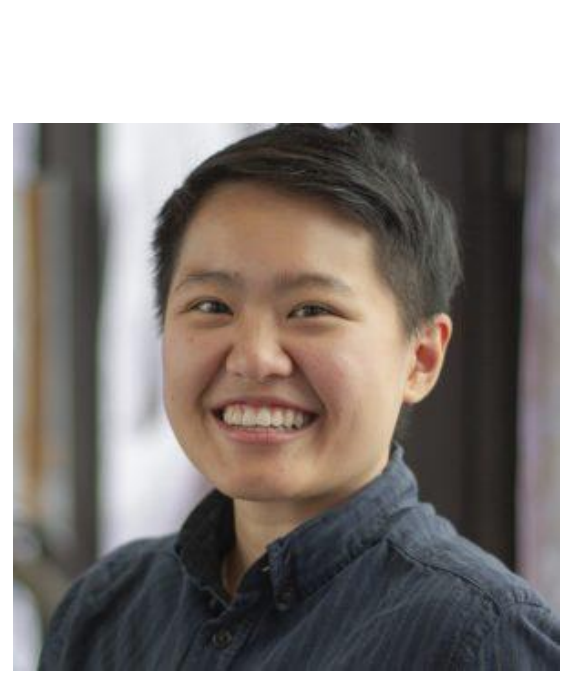

\section{About the Author}

They are a Queer Transgender Second-Generation Hmong American Citizen; and their professions consists of being a secondary education English teacher, visual artist (2D/3D mediums), radio producer, and community organizer. As a Gates Millennium Scholar, Yang recently graduated from Augsburg University with a Secondary Education in Communication Arts and Literature Bachelor of Arts degree.

Under their film production company, PY Production, Yang produced their first feature film, Taboo; depicting a groundbreaking love story with a vision to inspire and change the perspective of love in the Hmong community. They are also a co-producer of Nplooj Radio, a Hmong LGBTQIA+ radio show that provides a brave space for marginalized/underrepresented communities through arts, music, culture, and dialogues. 


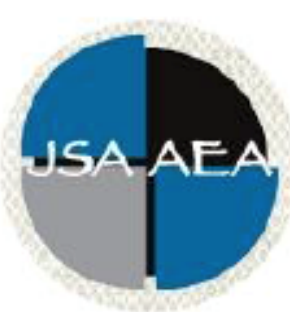

Vol. 15 Iss. 2 Special Issue (2020) $\quad$ www.JSAAEA.org

Special Issue Co-Editors

Dr. Peter T. Keo

Stanford University

Dr. Loan Thi Dao

St. Mary's College of California

Editor

Dr. Wayne E. Wright

Purdue University

Associate Editors

Dr. Chhany Sak-Humphry

University of Hawaii at Manoa

Dr. Phitsamay Sychitkokhong Uy

University of Massachusetts, Lowell

\author{
Book Review Editor \\ Dr. Vichet Chhuon \\ University of Minnesota \\ Creative Works Editor \\ Bryan Thao Worra \\ Lao Assistance Center \\ Journal Manager \\ Fang Gao \\ Purdue University
}

\title{
Editorial Review Board
}

Dr. Steve Arounsack

California State University, Stanislaus

Dr. Sovicheth Boun

Salem State University
Dr. Carl L. Bankston III

Tulane University

Dr. Phala Chea

Lowell Public Schools 


\author{
Dr. Virak Chan \\ Purdue University \\ Dr. Loan Dao \\ St. Mary's College of California \\ Dr. Changming Duan \\ University of Missouri-Kansas City \\ Dr. Sothy Eng \\ Lehigh University \\ Dr. Vincent K. Her \\ University of Wisconsin, Eau Claire \\ Dr. Peter Nien-Chu Kiang \\ University of Massachusetts, Boston \\ Dr. Kevin K. Kumashiro \\ University of Illinois, Chicago \\ Dr. Ha Lam \\ Independent Scholar \\ Dr. Jonathan H. X. Lee \\ San Francisco State University \\ Dr. Monirith Ly \\ Royal University of Phnom Penh \\ Dr. Bic Ngo \\ University of Minnesota \\ Dr. Leakhena Nou \\ California State University, Long Beach \\ Dr. Mark Pfeifer \\ SUNY Institute of Technology \\ Dr. Loan T. Phan \\ University of New Hampshire \\ Dr. Karen Quintiliani \\ California State University, Long Beach \\ Dr. Angela Reyes \\ Hunter College \\ The City University of New York \\ Dr. Fay Shin \\ California State University, Long Beach \\ Dr. Christine Su \\ College of San Mateo \\ Dr. Alisia Tran \\ Arizona State University \\ Dr. Khatharya Um \\ University of California, Berkeley \\ Dr. Kim Tran \\ University of California, Los Angeles, \\ Glendale Community College \\ Dr. Molly Wiebie \\ The University of Texas at Austin
}

Dr. George Chigas

University of Massachusetts, Lowell

Dr. Hien Duc Do

San Jose State University

Dr. Sophal Ear

Occidental College

Dr. Jeremy Hein

University of Wisconsin, Eau Claire

Dr. Nancy H. Hornberger

University of Pennsylvania

Dr. Peter Tan Keo

Stanford University

Dr. Yvonne Kwan

San Jose State University

Dr. Ravy Lao

California State University, Los Angeles

Dr. Stacey Lee

University of Wisconsin, Madison

Dr. Sue Needham

California State University, Dominguez Hills

Dr. Max Niedzwiecki

Daylight Consulting Group

Dr. Clara Park

California State University, Northridge

Dr. Giang Pham

University of Massachusetts Amherst

Dr. Malaphone Phommasa

University of Clifornia Santa Barbara

Dr. Kalyani Rai

University of Wisconsin-Milwaukee

Dr. Cathy J. Schlund-Vials

University of Connecticut, Storrs

Dr. Nancy J. Smith-Hefner

Boston University

Dr. Yer J. Thao

Portland State University

Dr. Monica M. Trieu

Purdue University

Dr. Silvy Un

Saint Paul Public Schools

Dr. Linda Trinh Vo

University of California, Irvine

Dr. Yang Sao Xiong

The University of Wisconsin-Madison

Dr. Zha Blong Xiong

University of Minnesota 


\section{Doctoral Student Editorial Review Board}

\author{
Diana Chandara \\ University of Minnesota-TwinCiteis \\ Linh Dang \\ University of Rochester \\ Annie BichLoan Duong \\ San Joaquin County Office of Education \\ Jacqueline Mac \\ Indiana University \\ Vanessa Sovanika Na \\ University of California SanDiego \\ Khoi Nguyen \\ George Mason University \\ Linda Marie Pheng \\ University of Wisconsin-Madison \\ Latana Thaviseth \\ University of California Los Angeles \\ Melissa Vang \\ San Diego State University \\ Soua Xiong \\ San Diego State University \\ Claremont Graduate University
}

Kassandra Chhay

University of Minnesota-Twin Cities

Bao Diep

University of Minnesota-Twin Cities

Nielson Hul

Cornell University

Dung Minh Mao

University of Minnesota-Twin Cities

Hoa Nha Nguyen

Boston College

Thien-Huong Ninh

University of Southern California

Krissyvan Truong

Claremont Graduate University

Mai Vang

University of Massachusetts Boston

Thong Vang

University of Minnesota-Twin Cities 